\title{
Inequalities and solidarities: interactions and impacts of sea-level-rise adaptation policies
}

\author{
Nathalie Long $^{1}$, Cécile Bazart ${ }^{2}$ and Hélène Rey-Valette ${ }^{2}$
}

\begin{abstract}
Drawing on the results of two research programs undertaken in France, we consider environmental inequality and regional solidarity in the context of adaptation to sea-level rise, given that there is in France a bespoke national system for natural-disaster solidarity. The analysis makes it possible to address situations of inequality, in particular related to risk, and regional institutional capacities as well as the types of solidarity (at spatial and temporal scales), by studying their impact on motivation and adaptation practices in terms of incentives or behavioral inertia. It also highlights seven interactions and discusses their effects. It emerges that insurance-based solidarity favors the status quo: by compensating or protecting, through dykes construction, the populations whose property is exposed to coastal hazards, this strategy maintains the environmental inequalities present on the coasts; the least well-off social groups participate in this financing without benefiting from better access to the coast (land or recreational activities). It also appears that the recent taxation system for funding the cost of palliative measures reinforces inequalities between coastal municipalities and hinterland municipalities and that differentiated forms of solidarity between the risk of erosion (uncompensated victims) and inundation (compensated victims) generate inequalities. Finally, it is noteworthy that inequalities reduce social, and strengthen intragroup, cohesion. The analysis of these relations reveals their somewhat negative effect on regional adaptation strategies to sea-level rise and calls into question the scales and modalities of solidarity whilst highlighting the key role of social cohesion as a factor of acceptability of regional restructuring programs in the face of sea-level rise.
\end{abstract}

Key Words: adaptation; climate change; environmental inequality; marine inundation; regional solidarity

\section{INTRODUCTION}

Coastal zones are attractive areas in terms of population and economic activity. There is an increasing trend toward coastal development with very high population densities found in coastal towns and numerous metropolises in coastal areas (Neumann et al. 2015). Such development has reinforced the unequal nature of the coastal areas, in particular through the exclusion of some social groups as a result of real estate prices. In France, according to the ONML (National Observatory of the Sea and the Coast), the price of coastal building land is over $25 \%$ higher than in the hinterland (ONML 2018). Hence, the greater proportion of higher socio-professional categories and retirees leads to inequality in access to real estate and to "privatization" and gentrification schemes (Kolb et al. 2014). However, this social inequality goes hand in hand with a specific exposure to erosion and inundation risks. In France, some 700,000 ha are classified as "low-lying areas" with over 1.4 million inhabitants currently exposed to the risk of inundation (MEDDTL 2012). Moreover erosion could affect, by 2040, 21,300 dwellings (with an estimated value of $€ 3.7$ billion), $2000 \mathrm{~km}$ of railway tracks and $20,000 \mathrm{~km}$ of roads.

In order to address coastal risks, different management strategies are possible, involving trade-offs mostly based on cost/benefit analyses depending on the cost of the assets to be protected and on the timing of the expected benefits (André et al. 2016). This approach involving the monetarization of costs and benefits leads to the exclusion of numerous social considerations, such as those related to individuals' capacities (Boda 2018) or social and environmental inequalities. Yet it is important to study the social impacts and the types of solidarity implied by the different technical strategies of adaptation to coastal hazards. Several strategies are implemented: managed retreat of infrastructure and properties, reinforcement of the coastal line (hard structures like dikes), nature-based solutions like revegetation or sand nourishment, and last, continuity in the use of exposed territories without preventing their exposure to a hazard, doing nothing (Williams et al. 2018). Hence, relocating the most exposed activities means restructuring regional development and projects, and creates population flows within, and even between, regions highlighting the need to re-think regional solidarity. Relocation promotes the maintenance, and even the development, of natural sea-front areas and thereby the resilience of coasts, which benefit users, tourists, residents, and day visitors from the hinterland. Conversely, protection by sea defenses (dikes) favors the status quo and may enhance existing inequalities (Long et al. 2021). Furthermore, in the medium-term, dikes have been shown to reduce beach size, under certain morphological conditions, affecting all users except for those living along the seafront who keep their view and privileged access to the sea. However, this kind of consequence for people is rarely mentioned, even though strategic choices may increase inequality and lead to feelings of injustice on the part of some social groups, residents, or coastal users (Cooper and McKenna 2008, Williams et al. 2018). Conversely, other strategies allow a migration of ecosystems, more or less naturally.

According to Brulle and Pellow (2006), coastal society is the result of a particular organization that produces environmental inequalities like unequal access to coast (for residence or recreational activities) or unequal capacity to call on the authorities and to defend their individual interest. A society marked by significant inequalities may appear less cohesive in the event of a disaster. The spontaneous solidarity, which is expressed immediately after the occurrence of an event, is born of the feeling of belonging to a community, to a group (Bayertz 1999, as cited 
in Keessen et al. 2016). If no one identifies this community or group, then this solidarity may be non-existent. Coastal risk management policies must therefore allow or, at least, not compromise the capacity of territories and societies to be more resilient, by being fairer and more equitable. Solidarity should allow the decrease of the gap between the advantaged and the less advantaged people (De Beer and Koster 2009, as cited in Keessen et al. 2016).

Resilience is here defined as "the capacity of a system to absorb disturbance and reorganize while undergoing change so as to still retain essentially the same function, structure, identity, and feedbacks" (Walker et al. 2004, as cited in Folke et al. 2010, Walker et al. 2010, Folke 2016). The resilience thinking argues that socialecological systems have to be managed to allow the emergence of new, flexible, and adaptable systems of operation and governance, rather than maintaining stability (Folke 2016). This thinking is all the more applicable in coastal environments, which, in their natural or anthropized state, remain a system in perpetual evolution. Indeed, because of their diversity of functions and links, natural coastal systems are seen as resilient (Costanza et al. 1995, Paskoff 2004). Policies for adapting to coastal hazards must consider this. Hence, they increasingly favor the use of soft solutions (natural infrastructure such as dune restoration and revegetation). According to Nelson et al. (2007:1), adaptation is "a process of deliberate change in anticipation of or in reaction to external stimuli or stress." Human actions are necessary to promote sustainable development in the face of hazards and because of an inevitable sea-level rise (Klein et al. 2003). This sustainable development, including some measures to adapt to climatic change, requires a society based on solidarity and justice to strengthen the policies acceptability and thus, their effectiveness.

We aim to study the relation between environmental inequalities and regional solidarities inherent to sea-level rise adaptation policies and to discuss to what extent these processes may (i) be strengthened or redressed by these adaptation policies and (ii) how they affect the effectiveness of adaptation policies. It is important therefore to analyze actions and feedbacks between solidarity and inequality, in order to present the issues surrounding environmental solidarity in all their complexity, particularly concerning its impact on the coastal areas' capacity to adapt to sea-level rise. To this end, we used the results of surveys undertaken as part of two research projects on metropolitan French coasts. These surveys on the management of coastal risk addressed issues such as regional attachment, risk perception, spatial and social justice, acceptability of adaptation policies (in particular relocation), trust in institutions, governance, and actor strategies. This discussion relies on a collective and post-hoc analysis of inequalities and solidarities using surveys where these themes were only one of the aspects taken into consideration.

\section{FRENCH CONTEXT: A COMPULSORY SOLIDARITY SYSTEM}

The issue of solidarity in response to natural disasters has a specific character in France, as there is a national system for compensation and for funding protection strategies. This system, called CAT NAT ${ }^{[1]}$, was set up by the government in 1982 in order to compensate for damages incurred when a disaster was declared at the level of a municipality. The system involves national solidarity by mutualizing insurance policy holders independently of the risk exposure (Clément et al. 2015) and is funded by a specific contribution from all insurance contracts $(12 \%$ from housing insurance and 6\% from vehicle insurance). Since 2005 , the sustainability of the system has been called into question because in some cases, for example storms Lothar in 1999 and Xynthia in 2010, the level of damages is such that public funds have to be drawn from the Central Reinsurance Fund (Caisse Centrale de Réassurance), supplemented by taxes. Given the expected increase in damage due to sea-level rise, a recent Senate report (Bonnefoy 2019) suggested increasing the insurance contributions from $12 \%$ to $18 \%$. This insurance system introduces inequalities (those not exposed to hazards pay to compensate victims of natural disasters) and this increase would only reinforce them. In addition, this unfair system excludes damages generated by erosion (given that the process can be anticipated), which is strongly criticized, in particular as the erosion process is worsened by increasingly violent storms. Recent government communications on the development of policies to address the mounting risk add to this differential treatment. The suggestion is to integrate erosion into intercommunal regional development policies and to create a specific fund financed by an increased tax on real-estate transactions solely in coastal inter-municipalities (Buchou 2019) ${ }^{[2]}$. This specification restricts solidarity to coastal intermunicipalities and excludes contributions from nearby cities where recreational users of the coastal amenities also live. Finally, since 2018, the government has transferred the responsibility for the Management of Aquatic Environments and Flood Prevention (GEMAPI, integrating inundation management) to the intermunicipalities and created a new tax to fund protection works, which is collected at the relevant inter-municipalities level and capped at $€ 40$ /annum per inhabitant.

\section{ENVIRONMENTAL INEQUALITIES AND SOLIDARITY IN THE FACE OF COASTAL RISKS}

\section{Conceptualizing inequality and solidarity}

Following the rise in environmental concerns, the issues of environmental inequality and justice are increasingly under scrutiny, with a certain predominance at the international level of the notion of environmental justice. As a consequence, the concept of inequality gradually increases in importance, in particular in the French literature, since the early 2000s. In order to differentiate between these two notions, Brulle and Pellow (2006) explain that environmental justice occurs when "all people and communities are entitled to equal protection of (sic) environmental and public health laws and regulations" (Bullard 1996, as cited in Brulle and Pellow 2006) and conversely that environmental inequalities emerge when "a specific social group is disproportionately affected by environmental hazards" (p. 2). More generally, environmental inequalities may be defined as social intra- and inter-generational inequalities determined partly by the state of the environment and partly by social structuring (Deldrève 2015). Groups do not all have the same capacity to influence policies to preserve their environment and access to natural resources and amenities (Pye et al. 2008). Brulle and Pellow (2006) also defend the idea that environmental inequalities are the product of society and social dynamics, which creates specificities for coastal areas, depending in particular on adaptation strategies to coastal risks. The notion of environment 
is usually restricted to natural resources, but in some cases, it may be extended to include all the services contributing to living conditions in line with recent work on regional well-being (OECD 2018). In coastal environments facing coastal risks, environmental inequalities can be broken down into inequality of access to the coast as an amenity and place of residence, inequality of exposure to risks, and inequality in the capacity to mobilize public authorities (Kolb et al. 2014, Long et al. 2021). In addition to these regional inequalities, there are social inequalities (income, employment, education, gender, ethnic background, etc.) correlated to people's capacity to call on the authorities and to defend their individual interest (Sen 1997).

In France, as mentioned above, coastal regions benefit from a national solidarity institutional mechanism that compensates for damage and the organization of spontaneous local solidarity between coastal and other residents (donations, help with cleaning, etc.) in the aftermath of storms. On the other hand, inequalities can be studied at the level of territories (between coastal municipalities [urban and rural municipalities], or between coastal municipalities and inland municipalities close to the coast) and between social groups (Table 1).

Table 1. Details of environmental inequalities.

\begin{tabular}{|c|c|}
\hline $\begin{array}{c}\text { Between coastal and } \\
\text { hinterland populations } \\
(\mathrm{A}) \\
\end{array}$ & $\begin{array}{c}\text { Between coastal municipalities and between } \\
\text { urban or rural } \\
\text { municipalities (B) }\end{array}$ \\
\hline $\begin{array}{l}\text { Inequalities in access to } \\
\text { amenities and land } \\
\text { resources and in } \\
\text { economic development } \\
\text { opportunities }\end{array}$ & $\begin{array}{l}\text { (B1) Unequal exposure to erosion and/or } \\
\text { inundation depending on the geomorphology } \\
\text { resulting in differential access to solidarity funds } \\
\text { because these only concern inundation. } \\
\text { (B2) Inequalities in the institutional capacity to } \\
\text { implement adaptation policies }\end{array}$ \\
\hline
\end{tabular}

Solidarity is usually defined as the feeling that pushes human beings to offer mutual support, in particular between members of a group or a community sharing common interests and governance systems that make it possible to organize this solidarity at the relevant scale(s). Solidarity can take several forms, financial, material, institutional, and be spontaneous or managed. In any event, it implies differences in situations for which people are not responsible, in line with certain thinking in social justice (Dworkin 1981, Clément et al. 2015). According to Durkheim (1964), solidarity is a functional requirement for the existence and the survival of any social system. He distinguishes between mechanical solidarity, which connects individuals who are alike, and organic solidarity, which is based on people's interdependencies.

As part of a study on interactions between urban and rural populations for the management of water resources, Bots et al. (2007) suggested a solidarity typology that stresses the linkages between solidarity, environmental inequalities, and social cohesion. In fact, according to Segall (2005), solidarity develops from the individual's integration in the group, from the commitment to common good, from empathy, and from the trust within the group. Other types of solidarity may be described. For example, Miller (1999) alludes to the notion of integration to describe the case of a supportive individual who identifies with a group because of concerns he shares with the group: values, objectives, rules. This is the social dimension of solidarity. For Mason (1998), solidarity may result from a commitment to the common good and may be seen as the capacity to look beyond one's own interest for the sake of the common interest. In the same way, Keessen et al. (2016) distinguish voluntary solidarity from imposed solidarity and propose two types: a one-side solidarity to "assist community members in need" and a two-sided solidarity based on mutual dependence to defend a common interest. According to Cohen and Arato (1992), empathy may be an engine of solidarity in the sense that it involves altruistic motives for the well-being of others who are less well-off than oneself. Finally, solidarity actions require a feeling of trust in people in the case of personal interactions and trust in the institutions if solidarity is enacted (Segall 2005).

\section{Analytical framework for inequalities, solidarities, and adaptation interactions}

Independently of adaptation policies, it is recognized that large social inequalities compromise solidarity between classes because, as noted by Uslaner and Brown (2005), inequalities increase the social distances between groups and people and promote social enclaves, and so reinforce social inequalities. Hence, in societies where inequalities are great, there are more health and social problems and citizen participation is lower as a result of a sense of inferiority or precarious material circumstances (Wilkinson and Pickett 2009, Lancee and Van de Werfhorst 2012). Yet the acceptability of adaptation policies, especially relocations that require a deep change in reasoning, relies on strengthening the dialogue with residents and stakeholders. Increased inequalities may cause exclusion that would be damaging to the quality of this dialogue. If differences between individuals are markedly high, the sense of belonging to a group will suffer. These observations lead us to reflect on the reverse process, i.e., would a society based on solidarity promote policies and actions toward reducing inequalities? These issues are not generally addressed to any great extent, the emphasis being placed on the role of governance in terms of the coherence, trust, communication, participation, and legitimacy of the institutions responsible for policy implementation (Touili et al. 2014, Hino et al. 2017, Rocle 2017). Less studied, the issue of equity tends to focus more on characterizing inequalities (Clément et al. 2015, Rulleau et al. 2017) than on the effects of these policies on inequalities. Drawing on the lessons learnt from adaptation policies (Reckien et al. 2015, Hino et al. 2017, Aguiar et al. 2018) we identified a number of relations concerning interactions between solidarity and environmental inequalities and their impact on adaptation strategies for coastlines facing sea-level rise. In all, seven potential relations were defined:

$\mathrm{R} 1$ : Insurance-based solidarity maintains inequalities between communes and social groups.

\section{R2: Insurance solidarity maintains the status quo.}

R3: Insurance solidarity reduces the impact for the less well-off.

R4: Financing works through taxation enhances inequality between communes.

R5: Inequalities reduce social cohesion.

R6 Inequalities enhance intra-group solidarity.

R7: Differentiated solidarity affects inequalities (especially erosion and inundation). 
Table 2. Details of SOLTER survey characteristics.

\begin{tabular}{|c|c|c|}
\hline Type of survey and issue & Sample and survey modality & Date and area \\
\hline $\begin{array}{l}\text { Sessions of experimental economics (a variation of } \\
\text { the solidarity game of Selten and Ockenfels 1998) }\end{array}$ & $\begin{array}{l}191 \text { permanent residents in the experimental economics sessions } \\
\text { and } 258 \text { permanent residents in the surveys ( } 122 \text { in coastal } \\
\text { municipalities and } 136 \text { in the hinterland) }\end{array}$ & $\begin{array}{l}2014 \\
5 \text { municipalities of the Béziers } \\
\text { regional planning area, } 2 \text { on the }\end{array}$ \\
\hline $\begin{array}{l}\text { Perception survey focused on risk perception and } \\
\text { justice principles }\end{array}$ & $\begin{array}{l}\text { Self-administered questionnaire in the presence of the } \\
\text { researchers }\end{array}$ & $\begin{array}{l}\text { coast and } 3 \text { situated, respectively, } 18 \\
\mathrm{~km}, 29 \mathrm{~km} \text {, and } 40 \mathrm{~km} \text { away from } \\
\text { the coast }\end{array}$ \\
\hline $\begin{array}{l}\text { Survey of stakeholders' perceptions using a few key } \\
\text { questions }\end{array}$ & $\begin{array}{l}30 \text { elected representatives and } 33 \text { stakeholders surveyed by focus } \\
\text { group with electronic voting devices }\end{array}$ & $\begin{array}{l}2015 \\
\text { Béziers regional planning area }\end{array}$ \\
\hline
\end{tabular}

These relations emphasize the role of insurance in creating inertia (Werners et al. 2021) with contrasted effects on inequalities when, as in France, the system is based on strong solidarity and is not proportional to exposure, and excludes the erosion risk that is deemed to be foreseeable. Likewise, the financial and tax resources related to the population may increase inequalities between municipalities or lead to remedial strengthened urbanization strategies inconsistent with effective adaptation. The analysis of interviews and surveys enables investigation of whether these relations are verified or not and to what extent they act as strengths or constraints with respect to a coastal area's adaptation to sealevel rise.

\section{METHODOLOGY}

\section{Study areas}

The study sites are located along the Mediterranean and the Atlantic. Both cases involve sandy coastlines highly at risk of erosion and inundation even if the Mediterranean is differentiated by its smaller beaches and absence of tides.

The Mediterranean study site (SOLTER Project), situated along the coast, comprised all the municipalities belonging to the SCOT (regional planning arrangement) around Béziers ${ }^{[3]}$, that is to say coastal as well as hinterland municipalities so as to examine solidarities as a function of distance from the coast. This coastal area is situated in the Hérault department, the most vulnerable in the Occitanie region. The studied area comprises $30 \mathrm{~km}$ of coast, some $15 \%$ of the regional beachline, and is one of the most important camping zones along the French seaside.

The Xynthia storm was the triggering event on the Atlantic coast that put back on the agenda the indispensable management of natural marine hazards. Xynthia generated a storm surge that reached its maximum in the middle of the Bay of Biscay with a maximum of $1.5 \mathrm{~m}$ recorded by the tide gauge in La Pallice, La Rochelle, at the same time as the high tide, which led to a total water level of $8.01 \mathrm{~m}$ above chart datum in La Pallice (Bertin et al. 2012). In addition to these extreme events, sea-level tends to rise by around $3 \mathrm{~mm} \cdot \mathrm{yr}^{-1}$ in the context of global change (Marcos et al. 2007, Dodet et al. 2019). The INEGALITTO project was undertaken on the Atlantic coast in Greater La Rochelle (specifically in Aytré municipality) and Charron municipality, in the north of the Charente-Maritime department, to address the coastal management strategies and their impacts in terms of environmental inequalities. Aytré is located in the inner suburbs of La Rochelle and enjoys all the services inherent in its proximity to a highly residential urban center, whereas Charron is dominated by agricultural and shellfish farming activities. Following storm Xynthia, many dwellings were destroyed in both places. However, a dike was rapidly rebuilt in Aytré (the existing dike was repaired and raised) but it took around 10 years before the decision was made to build a dike to protect the northern side of Charron.

As regards risk perception, the Atlantic coast is strongly affected by the memory of storm Xynthia, which in February 2010 caused 59 deaths and extensive damage especially in a housing estate built below the dike ( 29 deaths). On the other hand, the most violent Mediterranean storms date further back (1982 and 1997), which reduces risk memory.

Sun-seeker migration is very significant in the Mediterranean and entails large numbers of new arrivals along the coast with no experience of coastal risk. These disparities are reflected in the significant differences found in the implementation of adaptation policies. Hence following Xynthia, i.e., in a situation of crisis, nearly 1200 dwellings (15 municipalities) in Vendée and CharenteMaritime were purchased by the State and demolished for a budget of around $315 \mathrm{M} €$ (André 2013). By contrast, in the Mediterranean, relocation has focused primarily on coastal roads in an anticipatory fashion. It should be noted that on both sites, there were no earlier studies concerning the perceptions and the behavior of people; most of the work focused on monitoring the coastline and evaluating vulnerability. In Occitanie, a study was undertaken to evaluate, under different adaptation scenarios, the regional damage generated by a one-meter rise in sea-level by 2100 (Hérivaux et al. 2018). The damage related to exposed dwellings is noteworthy $(34,000$ dwellings, i.e., $48 \%$ of damages in the "laisser-faire" scenario).

\section{Survey characteristics}

Our discussion draws on quantitative and qualitative surveys undertaken as part of two research projects intended to address the situations and the perceptions of residents with respect to coastal risks and the impacts of adaptation policies. A specific and comparative analysis of the results was structured around the interactions between adaptation, solidarity, and inequality.

\section{Mediterranean coast survey (Occitanie region)}

The SOLTER project ${ }^{[4]}$ undertaken in partnership with local managers aimed to analyze regional solidarities in relation to the resilience of coastal regions and in function of distance from the coast. The survey by questionnaire and focus groups (Table 2) made it possible to examine the types of justice criteria used with respect to the relocation acceptability and property compensation terms in the event of relocation (Rulleau et al. 2017). 
The surveyed population had the typical characteristics of the French coastal population with mostly couples (46\%), retirees (43\%), educated people ( $46 \%$ have a higher education diploma). Therefore, these are rather well-off people who are owners $(73 \%)$ of their detached house or villa $(70 \%)$ as their main residence. The survey respected the gender balance (54\%).

The questionnaire consisted of several modules with differences for respondents from coastal and non-coastal municipalities. The aim was to address coastal attachment, beach use, flood risk perception and relocation modalities. One module on justice criteria and the forms of solidarity questioned the residents on the compensation criteria they considered the fairest and their preferences on whether relocation funding should be solidaritybased or not.

The Atlantic coast survey (Nouvelle Aquitaine region)

After the Xynthia storm, the INEGALITTO project ${ }^{[5]}$ aimed to analyze environmental inequality in the management of coastal amenities and risks and, in particular, the extent to which risk and vulnerability management policies affected such inequality (Long et al. 2019, 2021). The interview-based survey (Table 3) provided the means to analyze residents' representations of coastal risk in Aytré and Charron municipalities, to address the issue of compensation for households exposed to coastal risk and to compare differential treatment between areas.

Table 3. Survey on the dual relationship with coastal risks and amenities: observation of environmental inequalities.

\begin{tabular}{lll}
\hline \hline Date & Sample & Area (Department) \\
\hline 2017 & $\begin{array}{l}\text { 28 interviews (3 association managers, } \\
\text { 5 elected representatives or technical } \\
\text { department managers, 18 residents, and }\end{array}$ & $\begin{array}{l}\text { Districts of Les Marais } \\
\text { salant and Pierre Loti in } \\
\text { Aytré (Charente Maritime) }\end{array}$ \\
$2018 \begin{array}{l}\text { 2others). } \\
\text { elected representatives, 20 residents of } \\
\text { whom 6 were disaster-stricken, and 8 } \\
\text { others) }\end{array}$ & $\begin{array}{l}\text { Municipality of Charron } \\
\text { (Charente Maritime) }\end{array}$ \\
\hline
\end{tabular}

The cross-sectional analysis of the results obtained as part of the two projects made it possible, by integrating various typologies from the literature, to study systematically the interactions between solidarity mechanisms and practices, and inequalities. Reviewing these results allows us to question above-mentioned relations on the impacts of these unequal situations and solidarity practices on the adaptation capacity of coastal areas. These relations are the main contribution of this study. They are presented in the discussion once the observations justifying them have been described.

\section{OVERVIEW OF INEQUALITIES AND SOLIDARITIES}

Based on our typology of inequalities (Table 1) and considering the various forms of solidarity, among which some are specific to France, we aim to describe all the possible situations relying on the results of the relevant surveys. Let us recall that, on the one hand (INEGALITTO project on the Atlantic coast) the analysis is based on the observation of actions carried out after the major Xynthia storm, while, on the other hand (SOLTER project in the Mediterranean) it is a question of exploring before the storm and the perceptions and expectations about the modalities of implementation of adaptation policies. Both, supported by the literature, support that a diversity of situations and types of inequalities and solidarity scheme exist. Therefore, this analysis aims to identify the types of relationships that are plausible in relation to adaptation policies in order to characterize how the type and combination of inequalities and solidarities constitute a strength or a limitation for adaptation policies.

\section{Diversity of inequality sources}

Inequalities between coastal and hinterland inhabitants in access to real estate and in economic development (Class A)

The analysis, undertaken as part of the INEGALITTO project, confirmed the great attractiveness of coastal areas with a high population density leading to better levels of equipment, services, and infrastructure than in the hinterland areas. However, this attractiveness generates a strong pressure on the real estate market with high prices that reduce access to the coast for low-income households. This inequality in access is also physical in the sense that there are situations where the coastline is quasi-privatized and the number of accesses to the sea and the beach, a common good, is reduced (Kolb et al. 2014, Long et al. 2019). However, this attractiveness varies according to the type of area in favor of sandy coasts, and even cliffs, rather than muddy shorelines. These differences in attractiveness determine economic orientations that might be residential and tourism-based or production-based around activities such as shellfish culture or agriculture and result in differences in resources and wealth.

\section{Inequalities of situation between coastal municipalities with} respect to the type of risk (Class B1)

First, it is worth reiterating that depending on their geomorphological characteristics and anthropization dynamics, coastal areas are not exposed to the same level and modalities of risk from marine weather hazards. Hence, areas are not equal in the face of coastal risk and there are differences in their vulnerability to erosion. As previously noted, as erosion can be anticipated, it cannot be included in natural disaster insurance compensation systems. This leads to differential treatment, which is widely condemned in the affected areas.

\section{Inequality between coastal municipalities in the treatment of} territories and in the institutional capacity (Class B2)

The differences in development lead to inequalities in the capacity of governance mechanisms to hold the authorities to account in the negotiation of decisions taken at the national level. Hence, in the Charente Maritime department, areas were treated very unequally following storm Xynthia: the solidarity areas ${ }^{[6]}$ initially planned on the Ile de Ré (famous isle close to La Rochelle, Atlantic coast) failed to materialize whereas some 180 houses were demolished in Charron and a further 60 in Aytré. A comparison of the average price of real estate (house) in the three municipalities $^{[7]}$ gives an indirect indication of these capacity differences: 7582 euros $/ \mathrm{m}^{2}$ in Portes-en-Ré on the Ile de Ré, 2668 euros $/ \mathrm{m}^{2}$ in Aytré, and 1876 euros $/ \mathrm{m}^{2}$ in Charron. More generally, decisions based on a cost-benefit approach tend to maintain the better-off along the coast as sea defenses have been built whereas less well-off municipalities, in particular less densely populated rural ones, have seen part of their built heritage demolished and a number of their inhabitants relocated. Hence Charron lost more than 400 residents between 2010 and 2013 (INSEE, https://www. 
insee.fr/fr/statistiques/2028604 and https://www.insee.fr/fr/ statistiques/2011101?geo=COM-17091\#chiffre-cle-1), i.e., an $18 \%$ drop in its population. Furthermore, although some people, protected by sea defenses, chose to stay on the coast, others, whose dwelling the government did not offer to repurchase, felt trapped by their situation, unable to move away because their property had lost its value. This regional differential treatment in the aftermath of storm Xynthia was worsened by differences in file processing times: in Charron protective arrangements were only approved at the beginning of 2018 (as part of the PAPI, an action and protection program against floods) whereas by that date, those on the Ile de Ré were $70 \%$ completed.

\section{Inequalities perception}

The surveys in the Charente Maritime department revealed a strong sense of injustice from both residents and elected representatives. However, few people consider themselves to be victims of inequality, they speak instead of injustice and unfair treatment compared to other regions. This feeling can be compared with the surveys undertaken as part of the SOLTER project, which ranked the justice criteria as the one most likely to promote the acceptability of relocation policies (Table 4). All types of respondents opted for the sustainability criterion but residents and stakeholders were less committed to the criteria of solidarity and the legitimacy of the institutions responsible for these policies. Conversely, elected representatives were more sensitive to sustainability and solidarity.

Table 4. Preferences concerning justice criteria promoting relocation acceptability (Source: LAMETA laboratory survey 2013 and 2017).

\begin{tabular}{lccc}
\hline \hline & $\begin{array}{c}\text { Popula- } \\
\text { tion }\end{array}$ & $\begin{array}{c}\text { Stakehol- } \\
\text { ders }\end{array}$ & $\begin{array}{c}\text { Elected } \\
\text { representatives }\end{array}$ \\
\hline $\begin{array}{l}\text { Sustainability (solutions must benefit } \\
\text { future generations) }\end{array}$ & $37 \%$ & $35 \%$ & $44 \%$ \\
$\begin{array}{l}\text { Efficiency (greatest impact per euro } \\
\text { spent) }\end{array}$ & $29 \%$ & $30 \%$ & $4 \%$ \\
$\begin{array}{l}\text { Dialogue (policies must be discussed } \\
\text { with the affected inhabitants) }\end{array}$ & $17 \%$ & $20 \%$ & $7 \%$ \\
$\begin{array}{l}\text { Solidarity (solidarity of all in the face } \\
\text { of a risk that will only affect a few) }\end{array}$ & $9 \%$ & $5 \%$ & $33 \%$ \\
$\begin{array}{l}\text { Governance (policies must be defined } \\
\text { and implemented by a legitimate } \\
\text { institution) }\end{array}$ & $8 \%$ & $10 \%$ & $11 \%$ \\
\hline
\end{tabular}

\section{Main types of solidarities}

\section{Spatial solidarity}

Although the sustainability of the French insurance system for natural disasters, based on national solidarity, has been discussed by numerous institutional stakeholders (Bonnefoy 2019, Buchou 2019), it is interesting to revisit the perceptions of residents on maintaining this system and, thereby, on the legitimacy of mutualizing compensations at a national scale. The surveys undertaken as part of the SOLTER project showed that $44 \%$ of the residents surveyed and $33 \%$ of the elected representatives in the regional planning area (SCOT) thought that all insurance contract premiums would increase without calling into question the current national solidarity. On the other hand, $26 \%$ of residents and $42 \%$ of elected representatives thought that premiums would come to depend on risk exposure and $30 \%$ of residents and $25 \%$ of elected representatives felt that frontline assets would eventually become uninsurable. As regards solidarity to fund inundation and erosion works, $37 \%$ of the residents surveyed preferred a non-solidarity-based funding system (coastal commune taxes, tourism taxes, or individual insurance schemes) whereas others supported funding based on allocated levies and taxes at a regional level $(7 \%)$ or at a national level $(53 \%)$. The interviews of the Aytré residents undertaken as part of the INEGALITTO project confirmed to some extent that households further away from the seafront are more inclined to question their financial contribution to building and/or maintaining a dike to protect people who "choose" to stay close to the sea. Finally, the SOLTER project survey made it possible to study the perceptions on the compensation systems considered to be the fairest in case of relocation, given that currently compensation is based on the market price and does not take risk exposure into account. The priority was given, in roughly the same proportions, to permanent residents $(30 \%)$ and keeping compensation based on market price (29\%; Table 5), with, however, some differences by region with the responsibility principle being more often expressed in the hinterland and the market price more frequently along the coast (Clément et al. 2015).

Table 5. Justice principles determining compensation mechanisms in case of relocation (Source: LAMETA laboratory survey 2013).

Depending on the nature of the dwelling (higher compensation $30 \%$

for permanent residents).

Depending on the market price of the property (standard $\%$ of the market value of the property).

According to the purchase date: new owners informed of the risk $\quad 14 \%$ at purchase will receive less compensation.

According to the owner's income (the less well-off will receive $\quad 12 \%$ more compensation).

According to the date of purchase: owners who have been there longer should be better compensated as they are more attached to their home. Other or no answer. $10 \%$ $5 \%$

Finally, experimental economics sessions were organized as part of the SOLTER survey, using a variation of Selten and Ockenfels 'solidarity game' $(1998)^{[8]}$, in order to test solidarity toward people at risk as a function of distance from the coast. Overall, $80 \%$ of participants contributed to the solidarity fund, with the contribution resembling a kind of self-insurance in the case of people at risk. The average contribution decreased with the distance between the dwelling and the shoreline: in the case of coastal municipalities and Béziers (18 km away from the sea) the contribution was 4.74 euros versus 3.8 euros in hinterland municipalities (respectively 29 and $40 \mathrm{~km}$ away from the sea). Furthermore, those who did not contribute to the game often chose funding, which was not based on solidarity in the perception section of the survey.

\section{Solidarity over time}

The literature shows that solidarities may be of different types and more or less sustainable depending on storm occurrence. A sincere and strong solidarity is usually shown following a disaster but it tends to disappear over time. However, within the Charron 
Fig. 1. Relations concerning interactions and impacts of inequalities and solidarity on adaptation to sea-level rise

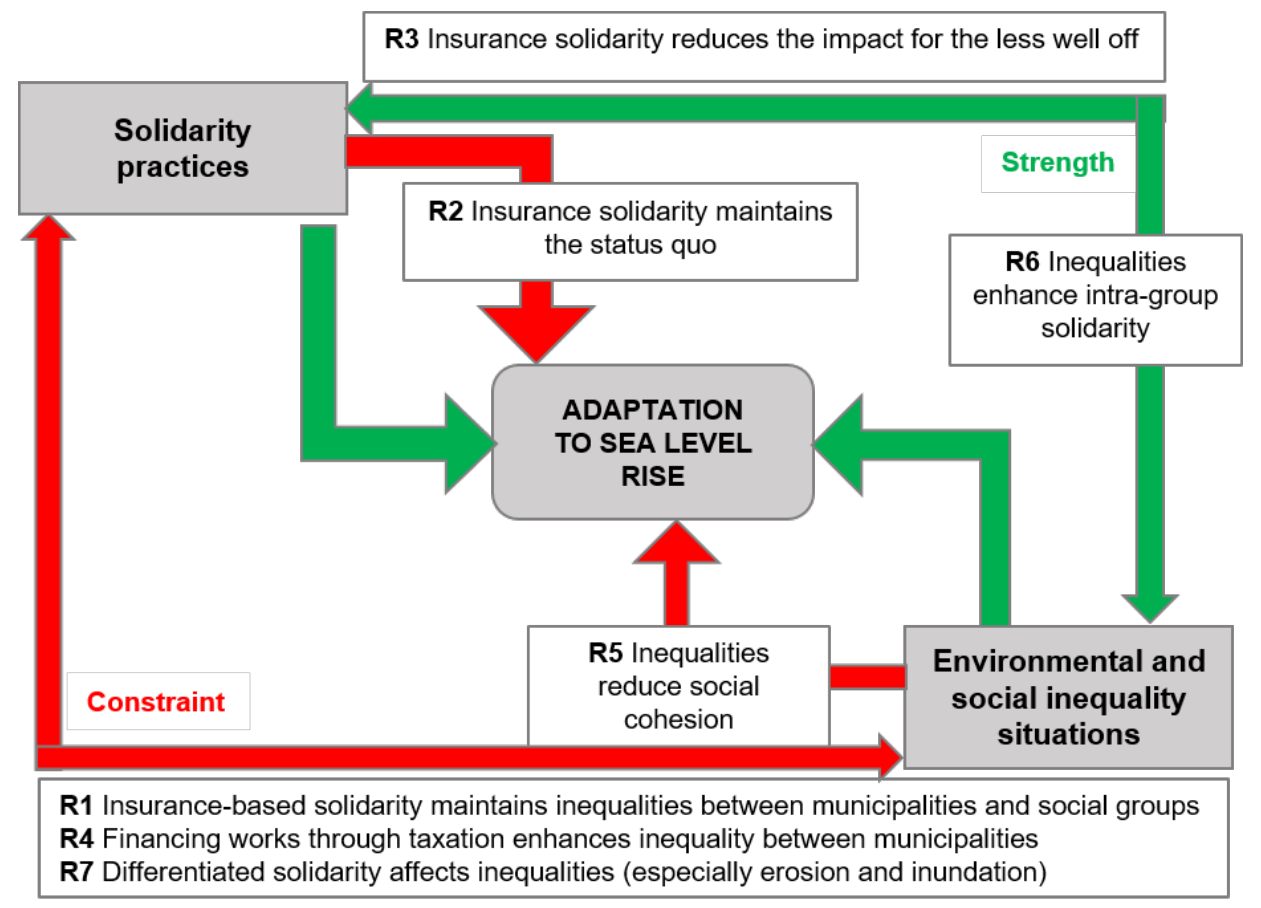

rural municipality, sharing a common experience built an interpersonal solidarity between residents who lived through the trauma of storm Xynthia, which continues, but this is less the case in Aytré. The feeling of belonging to a community that has suffered the same ordeal and shared the same fate (Deldrève and Candau 2015) is strengthened by the treatment, both in the management of the aftermath and in the prevention of future inundation risks, that differentiates between Charron and more attractive areas from residential and tourism viewpoints, such as the Ile de Ré. Furthermore, it is noteworthy that a "risk culture" in the sense described by managers remains high in Charron whereas in Aytré the issue is to distance oneself from the risk, integrating it as an "ordinary risk" and generating sometimes the feeling of a form of super-precaution in the community.

\section{Solidarity with nature}

The final form of solidarity observed was with nature (Bots et al. 2007). Still in the context of relocation, it promotes the protective role of beaches and natural areas as natural storm protection infrastructure (Lee et al. 2011). Hence, in the Aytré region, the residents interviewed, in particular the better-off, organized to ensure their voice was heard, value the return of the bay to its natural state, following the demolition of the houses and the hotel/ restaurant, coupled with the sand nourishment of the dune. They wish to preserve the natural aspect of the seafront and its identity, which differs markedly from nearby seaside resorts.

\section{IMPACTS OF INEQUALITIES AND SOLIDARITIES ON ADAPTATION POLICIES}

The previous analysis of the details and range of the situations of inequality as well as any mechanisms of solidarity is synthesized here according to their impacts on the adaptation policies. As stated in the introduction, our purpose is to study the extent to which these situations of inequality, particularly spatial ones, and that of the mechanisms of solidarity have a positive or negative influence on adaptation policies, but also to study their potential feedback effects on initial inequalities or solidarity level. It is therefore a question of characterizing the observations made according to the types of relationships to which they more closely correspond. Thus, Figure 1 shows the structure of the interactions between (i) the situations of inequality and the modalities of solidarity in the face of coastal risks and (ii) the adaptation policies according to the seven relations previously identified (cf. analytical framework). Theses relations were organized into several groups that are expressed as strengths (green arrows in Fig. 1) or constraints (red arrows in Fig. 1).

A first group of relations suggests that insurance-based national solidarity maintains existing inequalities between municipalities and between social groups with regard to access to coastal amenities and real estate as well as exposure to marine weather hazards. Effectively, given differences in income it explains for the most part the differences in people's adaptive capacity. Indeed, it tends to be well-off households (and often second-home owners) who live on the coast and are thus the most at-risk from marine hazards. When an inundation occurs, these households are compensated on the same basis as others that are less well-off. The national solidarity of the natural disaster system is applied indiscriminately regardless of household income. This system means that these households can keep their dwelling and continue indirectly to restrict access for other population categories. In this sense, this maintains inequality between areas as well as inequality in both real estate and physical access (R1 and R3). 
Moreover, this systematic disaster compensation arrangement may encourage irresponsible behavior by people at risk (Goeldner-Gianella and Longépée 2019) and it provides little incentive to question the place of residence or even the need for safety work to be carried out, such as the creation of another floor or roof access (Kreibich et al. 2005). However, this potential effect does depend on the financial means and ability to move of households (Rey-Valette et al. 2019a) with respect to their place of residence (R2). On this point, sociological or psychological factors such as attachment to the place must also be considered. However, a tiered yet still solidarity-based system could be designed that would not apply uniformly but according to certain collectively defined criteria. In particular, households that remained in zones at risk while being financially, physically, and psychologically able to move away would either receive no or partial compensation, or would be compensated degressively over time. The criteria used to define this population category could be income, the level of information on the risk incurred at the time of purchase, or inheritance, etc. In this regard, the recent report on operationalizing relocation (Buchou 2019) proposes to link compensation with risk awareness by creating observatories and by disseminating information to the mayor and estate agents. Hence, Theurer et al. (2018), in their modeling of owners' behavior in the face of sea-level rise in southern Florida, showed that the youngest owners (under 45) are more likely to move early and that middle-income groups are the ones least inclined to move. The authors stress the progressive risk of downgrading of municipalities, coupled with shortfalls in tax revenue depending on the mobility differentials between population types, leading to an eventual impact on their attractiveness.

The second group of relations addresses the spatial scale of solidarity as a factor that might affect inequality. In the aftermath of storm Xynthia, national solidarity assisted the department of Charente-Maritime, which highlighted the unequal treatment of regions depending on their capacity to hold state services and representatives to account. This differential treatment of municipalities concerns both the types of measure and the speed of implementation and is connected with regional engineering differences according to the size of municipalities. The provision of national solidarity shadows the cartography of regional environmental and social inequality, which it may even worsen. In municipalities that might be seen as "victims or left out," interpersonal solidarity continues between social groups affected by the storm whereas in municipalities that have a greater capacity to overcome the trauma, solidarity has progressively disappeared (R6). In Aytré, tensions between social groups re-emerged once the trauma and the post-crisis upsurge in solidarity had passed (R5). These processes support the work of Uslaner and Brown (2005) who noted a greater tendency toward social enclaves and reduced citizen involvement when inequalities are high and the social distance between groups is significant, and thereby reduced social cohesion.

These inequalities were exacerbated by the implementation of the GEMAPI tax in 2018, which moved solidarity to the intermunicipality level. This tax is calculated as a function of the number of persons per household, which generates inequalities that are proportionate to regional demography (R4 and R7). Finally, the development of solidarity with nature, which favors relocation, reduces inequalities of access to the coast for its amenity value and enhances its common good aspect with free access to the shore. However, this solidarity may generate a feeling of injustice among the people who are relocated and lose their privileged access to the sea and their sea view, often for the benefit of dwellings that used to be one row back.

\section{CONCLUSION}

Although most work on adaptation to sea-level rise centers on risk perception and the acceptability of policies and measures, our analysis seeks to address environmental inequalities and the regional solidarities that are implemented in the face of these risks. The aim is to study the extent to which these processes may either facilitate or restrict the implementation of adaptation policies. In the French case, this analysis is all the more important because the national solidarity system for natural disaster compensation is criticized for its status quo effect while its future financial equilibrium and sustainability are under scrutiny as damage is expected to increase in the long run. Our analysis highlighted several relations concerning the interaction between solidarity and environmental inequalities and showed their rather negative influence on regional adaptation strategies to rising sealevels. The analysis identified a wide range of unequal situations between populations both within and between regions (coastal and hinterland), concerning risk exposure, institutional capacity to act, and the choice and operationalization of adaptation measures. Given the diversity of unequal situations, the scales and modalities that define established solidarities must be examined as to their tendency to compensate for or enhance certain inequalities, in particular differentials in compensation that play a determinant role in residents' behavior and future regional attractiveness.

Analyzing, and taking account of, regional inequalities and solidarities is essential in defining the implementation modalities of adaptation policies, which are more easily accepted and more efficient if they are considered to be fairer and more equitable. People are increasingly sensitive to the fairness dimension and more generally to the institutional and social quality of public policies (Rey-Valette et al. 2019b) and wish to participate in the definition and ranking of allocation and redistribution criteria in public systems. Likewise, adaptation strategies come up against inertia related to governance (Zandvoort et al. 2017, Werners et al. 2021) and the level of social cohesion within communities affects the relevance of, and the commitment to, regional restructuring projects that may radically change the course of many historical dynamics. Furthermore, in the case of climate change, a consensual and coordinated approach for intervention strategies is essential, given that adaptation measures can be anticipated. Anticipation, which is essential to minimize future damages, implies specific conditions of agreement on common values and representations of risks, measures, and adaptation strategies. However, our work confirms the rather negative impact of inequalities and forms and scales of solidarity on social cohesion, requiring a strengthening of the social dimensions during the diagnostic phase (Adger et al. 2009, Graham et al. 2013). Managers should pay attention to these dimensions in the development and planning policies at local or regional level at the risk of increasing inequalities at local well-being level (OECD 2018). However, the funding of these local measures and the insurance and solidarity conditions usually rely on broader regional or national scales that involve other types of actors and 
more complex multi-level processes that must be articulated as recommended by Serra-Llobet et al. (2016). Finally, our analysis attaches more importance to social solidarities compared with the newer forms of solidarity with nature that imply some changes in values. These may be strengthened by awareness-raising measures and by favoring actions based on buttressing natural processes (Temmerman et al. 2013, Jaime et al. 2017).

[1] The "Natural Disaster" System, called CAT NAT in French from CATastrophes NATurelles, is financed by a Fund for the Prevention of Major Natural Hazards, known as the Barnier Fund from the name of the minister responsible for it.

${ }^{[2]}$ This tax would be $0.2 \%$ of transactions over $€ 100,000$ in order to integrate a social dimension in support of the less well-off. Funds would be allocated by a national committee based on the existence of a regional restructuring project. The collected amount is forecast to be $€ 54$ million per annum, i.e. $€ 800$ million by 2040 , which seems to meet the specific erosion management requirements on the basis of the recent diagnosis established by CEREMA (2019).

${ }^{[3]}$ Territorial Coherence Schemes (SCOT) are regional planning arrangements that enable local authorities to coordinate their choices in urban planning, housing, transport, environment, and economic development. The SCOT around Béziers, which is the pilot site for the study, comprises 270,000 inhabitants in 87 municipalities.

[4] Acronym of the title project: SOLidarité TERritoriale, translation: Territorial solidarity.

${ }^{[5]}$ Acronym of the title project: INEGAlités environnementales dans la gestion des aménités LITTOrales et des risques côtiers, translation: Environmental inequalities in the management of coastal amenities and risks.

[6] These areas, initially called "black areas," are those where building is no longer allowed and where existing buildings within its perimeter were demolished following storm Xynthia.

[7] Source: website used for real estate: https://www. meilleursagents.com

${ }^{[8]}$ People could contribute up to 10 euros to a fund intended for the protection of people at risk or could leave with the full amount.

Responses to this article can be read online at: https://www.ecologyandsociety.org/issues/responses. $\mathrm{php} / 13117$

\section{Acknowledgments:}

We would like to thank Nicole Lautrédou-Audouy, Valérie Deldrève, and Olivier Barreteau for their valuable insights during the development of this research work, as well as Camille Herbreteau and Beryl Costales for their work as engineer and Master's student. This work was supported by the French National Centre for Scientific Research (CNRS).

\section{Data Availability:}

The data that support the findings of this study are available on request from the corresponding author, Nathalie Long. None of the data are publicly available because they contain information that could compromise the privacy of research participants. Data from SOLTER project and INEGALITTO project address locally sensitive issues of risk management and may engage the responsibility of respondents. When these surveys were carried out, the RGPD (General Data Protection Regulation) was not in force in France, so the surveys are not anonymized. Ethical approval for this research study is not available because this regulation was not in effect at the time the surveys were conducted.

\section{LITERATURE CITED}

Adger, W. N., S. Dessai, M. Goulden, M. Hulme, I. Lorenzoni, D. R. Nelson, L. O. Naess, J. Wolf, and A. Wreford. 2009. Are there social limits to adaptation to climate change? Climatic Change 93:335-354. https://doi.org/10.1007/s10584-008-9520-Z

Aguiar, F. C., J. Bentz, J. M. N. Silva, A. L. Fonseca, R. Swart, P. Duarte Santos, and G. Penha-Lopes. 2018. Adaptation to climate change at local level in Europe: an overview. Environmental Science and Policy 86:38-63. https://doi.org/10.1016/j.envsci.2018.04.010

André, C. 2013. Analyse des dommages liés aux submersions marines et évaluation des coûts induits aux habitations à partir de données d'assurance. Perspectives apportées par les tempêtes Johanna (2008) et Xynthia (2010). Thèse de géographie. Université de Bretagne Occidentale, Brest, France.

André, C., D. Boulet, H. Rey-Valette, and B. Rulleau. 2016. Protection by hard defence structures or relocation of assets exposed to coastal risks: contributions and drawbacks of costbenefit analysis for long-term adaptation choices to climate change. Ocean \& Coastal Management 134:173-182. https://doi. org/10.1016/j.ocecoaman.2016.10.003

Bertin, X., N. Bruneau, J. F. Breilh, A. B. Fortunato, and M. Karpytchev. 2012. Importance of wave age and resonance in storm surges: the case Xynthia, Bay of Biscay. Ocean Modelling 42:16-30. https://doi.org/10.1016/j.ocemod.2011.11.001

Boda, C. S. 2018. From economic choice to social choice in coastal management: a critical assessment of the use of cost-benefit analysis in the evaluation of an erosion control project in Flager County, Florida, USA. Ocean \& Coastal Management 162:85-99. https://doi.org/10.1016/j.ocecoaman.2017.09.017

Bonnefoy, N. 2019. Rapport d'information au nom de la mission d'information sur la gestion des risques climatiques et l'évolution de nos régimes d'indemnisation. Rapport du Sénat, Paris, France. [online] URL: https://www.senat.fr/rap/r18-628/r18-6281.pdf

Bots, P. W. G., O. Barreteau, and G. Abrami. 2007. Simulation of solidarity in a resource sharing situation. ESSA 2007 - 4th Conference of the European Social Simulation Association10/, Sep 2007, Toulouse, France. [online] URL: https://hal.archivesouvertes.fr/hal-00468543

Brulle, R. J., and D. N. Pellow. 2006. Environmental justice: human health and environmental inequalities. Annual Review of 
Public Health 27(1):103-124. https://doi.org/10.1146/annurev. publhealth.27.021405.102124

Buchou, S. 2019. Quel littoral pour demain? Vers un nouvel aménagement des territoires côtiers adapté au changement climatique. Rapport remis à Monsieur le Premier Ministre et à Madame la Ministre de la Transition Écologique et Solidaire. Assemblée Nationale, Paris, France. [online] URL: https://www. ecologique-solidaire.gouv.fr/sites/default/files/2019.11.29 Quel-littoralpour-demain.pdf

Centre d'Études et d'Expertise sur les Risques, l'Environnement, la Mobilité et l'Aménagement (CEREMA). 2019. Évaluation des enjeux potentiellement atteints par le recul du trait de côte. CEREMA, Bron, France. [online] URL: https://www.cerema.fr/ system/files/documents/2019/10/evaluation enjeux potentiellement atteints_part_recul trait_cote_v_octobre 2019.pdf

Clément, V., H. Rey-Valette, and B. Rulleau. 2015. Perceptions on equity and responsibility in coastal zone policies. Ecological Economics 119:284-291. https://doi.org/10.1016/j.ecolecon.2015.09.005

Cohen, J., and A. Arato. 1992. Civil society and political theory. MIT Press, Cambridge, Massachusetts, USA. https://doi. org/10.4324/9781003060581-52

Cooper, J. A. G., and J. McKenna. 2008. Social justice in coastal erosion management: the temporal and spatial dimensions. Geoforum 39:294-306. https://doi.org/10.1016/j.geoforum.2007.06.007

Costanza, R., M. Kemp, and W. Boynton. 1995. Scale and biodiversity in estuarine ecosystems. Pages 84-125 in C. Perrings, K.-G. Mäler, C. Folke, C. S. Holling, and B. O. Jansson, editors. Biodiversity loss: economic and ecological issues. Cambridge University Press, Cambridge, UK. https://doi.org/10.1017/ CBO9781139174329.006

Deldrève, V. 2015. Pour une sociologie des inégalités environnementales, coll. EcoPolis, Peter Lang, Bruxelles, Belgium.

Deldrève, V., and J. Candau. 2015. Inégalités intra et intergénérationnelles à l'aune des préoccupations environnementales. Revue Françaises des Affaires Sociales 1-2:79-98. https://doi. org/10.3917/rfas.151.0079

Dodet, G., X. Bertin, F. Bouchette, M. Gravelle, L. Testut, and G. Wöppelmann. 2019. Characterization of se-level variations along the metropolitan coasts of France: waves, tides storm surges and long-term changes. Journal of Coastal Research 88:10-24. https://doi.org/10.2112/SI88-003.1

Durkheim, E. 1964. The division of labour in society. Free Press, New York, New York, USA.

Dworkin, R. 1981. What is equality? Part 2: equality of resources. Philosophy and Public Affairs 10:283-345.

Folke, C. 2016. Resilience (Republished). Ecology and Society 21 (4):44. https://doi.org/10.5751/ES-09088-210444

Folke, C., S. R. Carpenter, B. Walker, M. Scheffer, T. Chapin, and J. Rockström. 2010. Resilience thinking: integrating resilience, adaptability and transformability. Ecology and Society 15(4):20. https://doi.org/10.5751/ES-03610-150420
Goeldner-Gianella, L., and E. Longépée. 2019. Perceptions of extreme coastal events: the case of the French Atlantic and Mediterranean coasts. Pages 363-390 in C. Larrue and I. La Jeunesse, editors. Facing hydrometerological extreme events: a governance issue. John Wiley \& Sons Ltd, Hoboken, New Jersey, USA. https://doi.org/10.1002/9781119383567.ch23

Graham, S., J. Barnett, R. Fincher, A. Hurlimann, C. Mortreux, and E. Waters. 2013. The social values at risk from sea-level rise. Environmental Impact Assessment Review 41:45-52. https://doi. org/10.1016/j.eiar.2013.02.002

Hérivaux, C., H. Rey-Valette, B. Rulleau, A. L. Agenais, M. Grisel, L. Kuhfuss, L. Maton, and C. Vinchon. 2018. Benefits of adapting to sea level rise: the importance of ecosystem services in the French Mediterranean sandy coastline. Regional Environmental Change 18(6):1815-1828. https://doi.org/10.1007/ $\underline{\text { s10113-018-1313-y }}$

Hino, M., C. B. Field, and K. J. Mach. 2017. Managed retreat as a response to natural hazard risk. Nature Climate Change 7:364-370. https://doi.org/10.1038/nclimate3252

Jaime, D. E. G., K. O'Neill, and Z. Qiu. 2017. Coastal residents' perceptions of the function of and relationship between engineered and natural infrastructure for coastal hazard mitigation. Ocean \& Coastal Management 146:144-156. https:// doi.org/10.1016/j.ocecoaman.2017.07.005

Keessen, A., M. J. Vink, M. Wiering, D. Boezeman, W. Ernst, H. Mees, S. Van Broekhoven, and M. Van Eerd. 2016. Solidarity in water management. Ecology and Society 21(4):35. https://doi. org/10.5751/ES-08874-210435

Klein, R. J. T., R. J. Nicholls, and F. Thomalla. 2003. Resilience to natural hazards: how useful is this concept? Global Environmental Change Part B: Environmental Hazards 5:35-45. https://doi.org/10.1016/j.hazards.2004.02.001

Kolb, V., N. Long, and P. Marty. 2014. Is the coast a vector of socio-environmental inequalities in coastal urban areas? Proceeding of the Contemporary Urban Issues Conference, Istanbul, Turkey. [online] URL: https://hal.archives-ouvertes.fr/ view/index/identifiant/hal-01257977

Kreibich, H., A. H. Thieken, T. Petrow, M. Müller, and B. Merz. 2005. Flood loss reduction of private households due to building precautionary measures - lessons learned from the Elbe flood in August 2002. Natural Hazards and Earth System Sciences 5:117-126. https://doi.org/10.5194/nhess-5-117-2005

Lancee, B., and H. G. Van de Werfhorst. 2012. Income inequality and participation: a comparison of 24 European countries. Social Science Research 41:1166-1178. https://doi.org/10.1016/j. ssresearch.2012.04.005

Lee, F. C., J. R. C. Hsu, and W. H. Lin. 2011. Appraisal of storm beach buffer width for cyclonic waves. Coastal Engineering 58 (11):1049-1061. https://doi.org/10.1016/j.coastaleng.2011.06.005

Long, N., P. Cornut, and V. Kolb. 2019. Environmental inequalities on the coast of North Charente-Maritime department in exposure hazards. Proceeding of the ICE Coastal Management conference. N. Hardiman and the Institution of Civil Engineers, editors. La Rochelle, France, 24-26 September. https://doi.org/10.1680/cm.65147.143 
Long, N., P. Cornut, and V. Kolb. 2021. Strategies for adapting to hazards and environmental inequalities in coastal urban areas: what kind of resilience for these territories? Natural Hazards and Earth System Sciences 21:1087-1100. https://doi.org/10.5194/ nhess-21-1087-2021

Marcos, M., G. Wöppelmann, W. Bosch, and R. Savcenko. 2007. Decadal sea level trends in the Bay of Biscay from tide gauges, GPS and TOPEX. Journal of Marine Systems 68:529-536. https:// doi.org/10.1016/j.jmarsys.2007.02.006

Mason, A. 1998. Solidarity. Pages 23-25 in E. Craig, editor. Routledge encyclopedia of philosophy, Vol. 9. Routledge, London, UK. https://doi.org/10.4324/9780415249126-L097-1

Miller, D. T. 1999. The norm of self-interest. American Psychologist 54:1053-1060. https://doi.org/10.1037/0003-066X.54.12.1053

Ministère de l'Écologie, du Développement Durable des Transports et du Logement (MEDDTL). 2012. Stratégie nationale de gestion intégrée du trait de côte. Vers la relocalisation des activités et des biens. MEDDTL, Paris, France. [online] URL: http://webissimo.developpement-durable.gouv.fr/IMG/pdf/ sngitc 20120301 cle211b7c.pdf

Nelson, D. R., W. N. Adger, and K. Brown. 2007. Adaptation to environmental change: contributions of a resilience framework. Annual Review of Environment and Resources 32:395-419. https://doi.org/10.1146/annurev.energy.32.051807.090348

Neumann, B., A. T. Vafeidis, J. Zimmermann, and R. J. Nicholls. 2015. Future coastal population growth and exposure to sea-level rise and coastal flooding - a global assessment. PLoS ONE 10(6): e0118571. https://doi.org/10.1371/journal.pone.0118571

Observatoire national de la mer et du littoral (ONML). 2018. Prix des terrains à bâtir sur le littoral métropolitain en 2016 et évolution depuis 2006. ONML, France. [online] URL: https://ree. developpement-durable.gouv.fr/themes/milieux-et-territoires-a-enjeux/ mer-et-littoral/economie-et-demographie/article/prix-des-terrainsa-batir-sur-le-littoral-metropolitain-en-2016-et-evolution

Organisation for Economic Co-operation and Development (OECD). 2018. OECD regional well-being: a user's guide. OECD, Paris, France. [online] URL: https://www.oecdregionalwellbeing. org/assets/downloads/Regional-Well-Being-User-Guide.pdf

Paskoff, R. 2004. Potential implications of sea-level rise for France. Journal of Coastal Research 20(2):424-434. https://doi. org/10.2112/1551-5036(2004)020[0424:PIOSRF]2.0.CO;2

Pye, S., I. Skinner, N. Meyer-Ohlendorf, A. Leipprand, K. Lucas, and R. Salmons. 2008. Addressing the social dimensions of environmental policy - a study on the linkages between environmental and social sustainability in Europe. European Commission, Directorate-General Employment, Social Affairs and Equal Opportunities, Brussels, Belgium.

Reckien, D., J. Flacke, M. Olazabal, and O. Heidrich. 2015. The influence of drivers and barriers on urban adaptation and mitigation plans - an empirical analysis of European cities. PLoS ONE 10(8):e0135597. http://dx.doi.org/10.1371/journal.pone.0135597

Rey-Valette, H., S. Robert, and B. Rulleau. 2019b. Resistance to relocation in flood vulnerable coastal areas: a proposed composite index. Climatic Policy 19(2):206-218. https://doi. org/10.1080/14693062.2018.1482823

Rey-Valette, H., N. Rocle, D. Vye, L. Mineo-Kleiner, E. Longépée, C. Bazart, and N. Lautrédou-Audouy. 2019a. Acceptabilité sociale des mesures d'adaptation au changement climatique en zones côtières: une revue de dix enquêtes menées en France métropolitaine. VertigO Le revue électronique en sciences de l'environnement 19(2). [online] URL: https://journals.openedition. org/vertigo/26537

Rocle, N. 2017. L'adaptation des littoraux au changement climatique: une gouvernance performative par expérimentations et stratégies d'action publique. Thèse de sociologie. Université de Bordeaux, Bordeaux, France.

Rulleau, B., H. Rey-Valette, and V. Clément. 2017. Impact of justice and solidarity on the acceptability of managed realignment. Climate Policy 17(3):361-377. https://doi. org/10.1080/14693062.2015.1119097

Segall, S. 2005. Unconditional welfare benefits and the principle of reciprocity. Politics, Philosophy and Economics 4(3):331-354. https://doi.org/10.1177/1470594X05056607

Selten, R., and A. Ockenfels. 1998. An experimental solidarity game. Journal of Economic Behavior \& Organization 34:517-539. https://doi.org/10.1016/S0167-2681(97)00107-8

Sen A. 1997. Editorial: Human capital and human capability. World Development 25:1959-1961. https://doi.org/10.1016/ S0305-750X(97)10014-6

Serra-Llobet, A., E. Conrad, and K. Schaefer. 2016. Governing for integrated water and flood risk management: comparing topdown and bottom-up approaches in Spain and California. Water 8(10):445. https://doi.org/10.3390/w8100445

Temmerman, S., P. Meire, T. Bouma, P. M. J. Herman, T. Ysebaert, and H. J. de Vriend. 2013. Ecosystem-based coastal defence in the face of global change. Nature 504:79-83. https:// doi.org/10.1038/nature12859

Theurer, G., K. Broad, and R. Meyer. 2018. Using simulations to forecast homeowner response to sea level rise in south Florida: will stay or will they go ? Global Environmental Change 48:108-118. https://doi.org/10.1016/j.gloenvcha.2017.10.008

Touili, N., J. Baztan, J. P. Vanderlinden, I. O. Kane, P. Diaz-Simal, and L. Pietrantoni. 2014. Public perception of engineering-based coastal flooding and erosion risk mitigation options: lessons from three European coastal settings. Coastal Engineering 87:205-209. https://doi.org/10.1016/j.coastaleng.2014.01.004

Uslaner, E. M., and M. Brown. 2005. Inequality, trust, and civic engagement. American Politics Research 33:868-894. https://doi. org/10.1177/1532673X04271903

Walker, B. H., L. Pearson, M. Harris, K.-G. Maler, C.-Z. Li, R. Biggs, and T. Baynes. 2010. Incorporating resilience in the assessment of inclusive wealth: an example from South East Australia. Environmental and Resource Economics 45:183-202. http://dx.doi.org/10.1007/s10640-009-9311-7

Werners, S. E., R. M. Wise, J. R. A. Butler, E. Totin, and K. Vincent. 2021. Adaptation pathways: a review of approaches and 
a learning framework. Environmental Science and Policy 116:266-275. https://doi.org/10.1016/j.envsci.2020.11.003

Wilkinson, R., and K. Pickett. 2009. The spirit level. Why more equal societies almost always do better. Allen Lane, London, UK

Williams, A. T., N. Rangel-Buitragoc, E. Pranzini, and G. Anfuso. 2018. The management of coastal erosion. Ocean \& Coastal Management 156:4-20. https://doi.org/10.1016/j.ocecoaman.2017.03.022

Zandvoort, M., I. S. Campos, A. Vizinho, G. Penha-Lopes, E. K. Lorencová, R. van der Brugge, M. J. van der Vlist, A. van den Brink, and A. B. M. Jeuken. 2017. Adaptation pathways in planning for uncertain climate change: applications in Portugal, the Czech Republic and the Netherlands. Environmental Science \& Policy 78:18-26. https://doi.org/10.1016/j.envsci.2017.08.017 


\section{Appendix 1}

\section{Surveys (SOLTER project)}

\section{A) PLACE OF RESIDENCE, USE OF THE SEA AND BEACHES}

Why did you choose to live in your town? Choose 2 answers ranked by importance Choice 1 (the most important one)

Choice 2

\begin{tabular}{|l|l|}
\hline A. You were born or raised here & B. Because of the cost of housing \\
\hline C. Because of the proximity to work & $\begin{array}{l}\text { D. Because of the proximity to the } \\
\text { sea }\end{array}$ \\
\hline $\begin{array}{l}\text { E. Because of the proximity to family and close } \\
\text { friends }\end{array}$ & F. Other : Specify................ \\
\hline
\end{tabular}

What is the approximate number of times you go to the beach (in days per month)? In July and August In June and September The rest of the year

What do you think is the main interest of the existence of beaches for your municipality? 1 answer only

\begin{tabular}{|c|c|c|c|}
\hline$\square$ & Touristic and economic & $\square$ & A place of leisure for the inhabitants of the area \\
\hline$\square$ & Natural landscapes to be preserved & $\square$ & A source of demographic attractiveness \\
\hline$\square$ & A source of biodiversity & $\square$ & A zone of protection against storms \\
\hline
\end{tabular}

Do you think that your municipality benefits from the repercussions of the tourists' frequentation of the coast?

\section{\begin{tabular}{|l|l|l|l|l|l|l|l|l|} 
Not at all & $\square$ & No very little & $\square$ & Yes weakly & $\square$ & Yes a lot & $\square$ & I don't know \\
\hline
\end{tabular}}

\section{B) RISK PERCEPTION}

Frequencies of storms, memory of storms, types of effects, time to implement adaptation policies, effects of risks on property prices, on insurance contributions, gambling and general attitude in relation to the risk.

\section{C) SCENARIO FOR THE IMPLEMENTATION OF RELOCATION POLICY}

Choice of cards linked to a discreet choice experiment (six cards per questionnaire and three forms of questionnaire, i.e. 18 possible choices each between two scenarios on the modalities of adaptation and the status quo)

\section{D) CRITERION OF FAIRNESS OF ADAPTATION MEASURES}

In a situation of limited budget which measure do you think should be prefered ...

A less important and therefore less efficient retreat operation but allowing to better compensate people

A larger, more efficient operation with lower payouts 
To what type of investment do you think public budgets should be allocated in priority?

\begin{tabular}{|l|c|c|c|c|}
\hline & $\begin{array}{l}\text { Yes as a } \\
\text { priority }\end{array}$ & $\begin{array}{l}\text { Yes } \\
\text { depending on } \\
\text { the cost }\end{array}$ & No & $\begin{array}{c}\text { I don't } \\
\text { know }\end{array}$ \\
\hline $\begin{array}{l}\text { Public facilities (schools, hospitals, } \\
\text { roads, networks, etc.) }\end{array}$ & $\square$ & $\square$ & $\square$ & $\square$ \\
\hline Touristic activities & $\square$ & $\square$ & $\square$ & $\square$ \\
\hline $\begin{array}{l}\text { Economic facilities (business area, } \\
\text { shopping centers) }\end{array}$ & $\square$ & $\square$ & $\square$ & $\square$ \\
\hline To threatened houses & $\square$ & $\square$ & $\square$ & $\square$ \\
\hline To cultural heritage & $\square$ & $\square$ & $\square$ & $\square$ \\
\hline
\end{tabular}

Concerning the relocation of public facilities, which mode of public financing seems most fair to you? Choose 2 answers in order of importance.

\section{Choice 1 _ (the most important) Choice 2}

\begin{tabular}{|l|}
\hline A. They are public facilities, as a consequence regardless of their area, they must be financed \\
by national taxes \\
\hline $\begin{array}{l}\text { B. A specific tax for adaptation to climate change (eg car sticker for old age) could be levied } \\
\text { at the national level }\end{array}$ \\
\hline $\begin{array}{l}\text { C. These are coastal risks so their financing must rather result from regional and } \\
\text { departmental taxes }\end{array}$ \\
\hline $\begin{array}{l}\text { D. A specific tax for adaptation to climate change (eg car sticker for old age) could be levied } \\
\text { at the regional level }\end{array}$ \\
\hline $\begin{array}{l}\text { E. Only the inhabitants of coastal municipalities are concerned: as a consequence, local } \\
\text { taxes, only, should increase }\end{array}$ \\
\hline F. Tourism benefits the most from the beaches: there should be an increase in tourist taxes \\
\hline
\end{tabular}

For the relocation and compensation of private property (housing and activities), which mode of financing seems most fair to you? Choose 2 answers in order of importance

Choice 1 ___ (the most important) Choice 2

\begin{tabular}{|l|}
\hline A. They must be financed by national taxes because climate change concerns everyone \\
\hline $\begin{array}{l}\text { B. A specific tax for adaptation to climate change (eg car sticker for old age) could be levied } \\
\text { at the national level }\end{array}$ \\
\hline $\begin{array}{l}\text { C. These are coastal risks so their financing must rather result from regional and } \\
\text { departmental taxes }\end{array}$ \\
\hline $\begin{array}{l}\text { D. A specific tax for adaptation to climate change (eg car sticker for old age) could be levied } \\
\text { at the regional level }\end{array}$ \\
\hline $\begin{array}{l}\text { E. Only the inhabitants of coastal municipalities are concerned: as a consequence, local } \\
\text { taxes, only, should increase }\end{array}$ \\
\hline F. Tourism benefits the most from the beaches: there should be an increase in tourist taxes \\
\hline $\begin{array}{l}\text { G. Only exposed residents or activities are concerned: it should not be public funding, it is } \\
\text { up to individuals to ensure themselves contracting private insurance }\end{array}$ \\
\hline
\end{tabular}


What are the criteria that you consider most fair for the implementation of these policies of retreat?

Choose 2 answers in order of importance

Choice 1 (The most important)

Choice 2

\begin{tabular}{|l|}
\hline A. Efficiency: the greatest collective benefit per euro spent \\
\hline B. Solidarity: solidarity of all in the face of a risk that will affect only a few \\
\hline $\begin{array}{l}\text { C. Responsibility in the purchase: Individuals informed of the risk while purchasing are } \\
\text { responsible for their decision. }\end{array}$ \\
\hline $\begin{array}{l}\text { D. Equity: the situation of the most disadvantaged individuals in terms of income must be } \\
\text { taken into account }\end{array}$ \\
\hline E. Other : Specify $\ldots \ldots \ldots \ldots \ldots \ldots \ldots \ldots \ldots \ldots \ldots \ldots \ldots \ldots \ldots \ldots \ldots \ldots \ldots \ldots \ldots \ldots \ldots \ldots \ldots \ldots \ldots \ldots \ldots \ldots \ldots \ldots$ \\
\hline
\end{tabular}

What criteria do you think are the most important for these retreat policies to be accepted by the population? Choose 2 answer in order of importance

Choice 1 (the most important) Choice 2

\begin{tabular}{|l|}
\hline A. Efficiency: the greatest collective benefit per euro spent \\
\hline B. Sustainability: solutions should benefit future generations as well as our generations \\
\hline C. Solidarity: solidarity of all in the face of a risk that will affect only a few \\
\hline $\begin{array}{l}\text { D. Consultation: Policies must be defined through consultation with the inhabitants } \\
\text { concerned }\end{array}$ \\
\hline E. Governance: Policies must be defined and supported by a legitimate institution \\
\hline
\end{tabular}

E) SOLIDARITY CONCERNS

Which people, whom you would not know, do you feel the most in solidarity with? 1 answer only

\begin{tabular}{|l|l|}
\hline$\square$ & Victims of risks or natural disasters \\
\hline$\square$ & People with financial difficulties, for example unemployed people in need \\
\hline$\square$ & People with health problems \\
\hline$\square$ & Other : Specify $\ldots \ldots \ldots \ldots \ldots \ldots \ldots \ldots \ldots \ldots \ldots \ldots \ldots \ldots \ldots \ldots \ldots \ldots \ldots \ldots \ldots \ldots \ldots \ldots \ldots \ldots$ \\
\hline$\square$ & I don't know \\
\hline
\end{tabular}

Would you be ready to act? 1 answer only

\begin{tabular}{|l|l|l|l|}
\hline$\square$ & No & $\square$ & By helping people directly \\
\hline$\square$ & By making donations to associations & $\square$ & By a solidarity tax \\
\hline$\square$ & Other : Specify ............................ & $\square$ & I don't know \\
\hline
\end{tabular}

Are you a volunteer in one or more association (s) or organization (s)?

\begin{tabular}{|l|l|l|l|}
\hline$\square$ & Yes regularly (at least one day per week) & $\square$ & $\begin{array}{l}\text { From time to time (few days per } \\
\text { months) }\end{array}$ \\
\hline$\square$ & Momentarily (few days per year) & $\square$ & No \\
\hline
\end{tabular}

Have you made any donations to solidarity operations or various works during the past 12 months? 


\begin{tabular}{|l|l|l|l|l|l|}
\hline$\square$ & Yes, regularly & $\square$ & $\begin{array}{l}\text { Yes from time to time depending on } \\
\text { opportunities }\end{array}$ & No \\
\hline
\end{tabular}

\section{F) SOCIO DEMOGRAPHIC CHARACTERISTICS}

Gender, age, marital status, socio-professional category, number of brothers and sisters, number of children, level of education, link of activity with the sea, level of household financial resources. 


\section{Appendix 2}

\section{Semi-directive interview grid for the actors of the territory (INEGALITTO project) Presentation of the interview}

The interview is built around four main axes:

- The first axis concerns the respondent's position, the description of his/her functions, his/her professional career, the projects he/she is currently working on, his/her socio-professional characteristics, etc. (opening questions).

- The second axis is interested in the history and way of life of the commune, particularly those created in connection with the coastline: the particularities of the commune, the facilities, the key events, etc.

- The third axis focuses more on the organization of the commune (and more generally on the organization of public services) linked to the development and safety of the coastline: the main urban development orientations that are favored, the main difficulties in their application and the main points of crystallization of the issues, etc.

- The fourth axis focuses on the exchanges that exist within the municipality, between the population and the public authorities, concerning the development of the coastline and the management of its risks.

\begin{tabular}{|l|l|l|}
\hline Theme & Questions & $\begin{array}{l}\text { "what we would like to } \\
\text { know" }\end{array}$ \\
\hline $\begin{array}{l}\text { The history } \\
\text { of the } \\
\text { commune in } \\
\text { relation to the } \\
\text { coastline }\end{array}$ & $\begin{array}{l}\text { - Could you describe your city in a few } \\
\text { words? }\end{array}$ & $\begin{array}{l}\text { - Historically, how was [name of the city } \\
\text { built? Is this initial construction still the } \\
\text { of the municipality } \\
\text { - To which coastal risks is the commune } \\
\text { mainly exposed? } \\
\text { - Importance of the coastline } \\
\text { (or not) in the construction } \\
\text { of the municipality and } \\
\text { maintaining the influence of } \\
\text { the coastline in the current } \\
\text { territory } \\
\text { left their mark on our memories? How is } \\
\text { this memory of risk translated and therefore } \\
\text { taken into account? }\end{array}$ \\
$\begin{array}{ll}\text { of the coastal risk } \\
\text { - Integration of the risk in } \\
\text { the collective intelligence, in } \\
\text { the shared narratives and in } \\
\text { the prevention actions }\end{array}$ \\
\hline $\begin{array}{l}\text { The influence } \\
\text { of the coast } \\
\text { on urban } \\
\text { management }\end{array}$ & $\begin{array}{l}\text { - What are the major development } \\
\text { guidelines planned for the commune over } \\
\text { the next 20 years? What are the major } \\
\text { development guidelines planned in relation } \\
\text { to the coastline? (Enhancement, protection } \\
\text { works, specific developments, etc.) }\end{array}$ & $\begin{array}{l}\text { - Prioritisation of territorial } \\
\text { actions and positioning of } \\
\text { the coastline within the } \\
\text { prospective strategy of the } \\
\text { municipality }\end{array}$ \\
& $\begin{array}{l}\text { - Identification of the actors } \\
\text { (with a view to other } \\
\text { interviews) and }\end{array}$ \\
\hline
\end{tabular}




\begin{tabular}{|c|c|c|}
\hline & $\begin{array}{l}\text { - Who are the services that act on the } \\
\text { coastline? How are the actions of these } \\
\text { different services coordinated? } \\
\text { - What are the specific actions carried out } \\
\text { by the public authorities to prevent coastal } \\
\text { risks? } \\
\text { - What actions have been taken towards } \\
\text { tourists to prevent coastal risks? } \\
\text { - Have there been expropriations in your } \\
\text { commune because of the coastal risk? How } \\
\text { have they been experienced (by the } \\
\text { municipal services, by the inhabitants, by } \\
\text { associations, etc.)? } \\
\text { - Has the position held by the respondent } \\
\text { changed in relation to coastal risk issues } \\
\text { since he/she took on the responsibility? } \\
\text { - Are there exchanges with other } \\
\text { practitioners in the area on the subject of } \\
\text { coastal risks? If so, with which structures } \\
\text { and what kind of exchanges are these? } \\
\text { - Do urban planning documents dealing } \\
\text { with the issue of risks (PPRL, TRI, PAPI } \\
\text { studies, etc.) have an impact on the territory } \\
\text { and on the position in charge? if so, of what } \\
\text { nature? } \\
\text { - Are there any territorial projects in which } \\
\text { issues related to coastal risks are } \\
\text { predominant? }\end{array}$ & $\begin{array}{l}\text { schematisation of the } \\
\text { governance at work between } \\
\text { them } \\
\text { - Factual presentation of } \\
\text { prevention actions carried } \\
\text { out (of which the respondent } \\
\text { has knowledge) } \\
\text { - Level of political } \\
\text { positioning with regard to } \\
\text { coastal risk } \\
\text { - Level of confrontation of } \\
\text { communal projects with risk } \\
\text { issues and their management } \\
\text { - If "risk culture" is } \\
\text { mentioned: have a definition } \\
\text { of what is meant by risk } \\
\text { culture }\end{array}$ \\
\hline $\begin{array}{l}\text { The } \\
\text { population } \\
\text { facing the } \\
\text { coast }\end{array}$ & $\begin{array}{l}\text { - What exchanges are there with the } \\
\text { inhabitants about the coastal risk? } \\
\text { - What communication about coastal risk } \\
\text { exists for the inhabitants? What are the } \\
\text { media for this communication (oral, written, } \\
\text { illustrations, etc.)? } \\
\text { - The notion of resilience is gradually being } \\
\text { imposed in scientific and professional } \\
\text { discourse. Is this a term used with/by the } \\
\text { inhabitants with regard to coastal risk? } \\
\text { - In your opinion, how is the coastline } \\
\text { experienced by the inhabitants? as a risk? as } \\
\text { an asset? } \\
\text { - Are there any associations that act on the } \\
\text { coastline? Are you aware of any initiatives } \\
\text { taken by residents to prevent risks? } \\
\text { - Taking the example of Xynthia, how did } \\
\text { people organize themselves in the face of } \\
\text { the risk? What were the sources of }\end{array}$ & $\begin{array}{l}\text { - Level of exchange between } \\
\text { the public authority and the } \\
\text { inhabitants on the risk } \\
\text { - State of the real knowledge } \\
\text { of the risk by the } \\
\text { populations + } \\
\text { communication pedagogy } \\
\text { used (political positioning) } \\
\text { - Percolation of scientific } \\
\text { thought into the } \\
\text { practitioners' modes of } \\
\text { action } \\
\text { - Place of the coastline in the } \\
\text { representation of the } \\
\text { commune and in the } \\
\text { lifestyles of the inhabitants } \\
\text { - Importance of the coastline } \\
\text { in the life of the inhabitants }\end{array}$ \\
\hline
\end{tabular}




\begin{tabular}{|l|l|l|}
\hline $\begin{array}{l}\text { initiatives and assistance during this event? } \\
\text { (Town hall, MJC, associations, gymnasium, } \\
\text { public space, outside the commune...) } \\
\text { - In your opinion, what should be done to } \\
\text { improve the reactions of residents and } \\
\text { tourists to a coastal risk? }\end{array}$ & $\begin{array}{l}\text { + taking it in hand by the } \\
\text { inhabitants } \\
\text { - Illustration of reaction to } \\
\text { the risk and spatialization of } \\
\text { the reaction to the risk (it is } \\
\text { concerning urban planning documents } \\
\text { dealing with the issue of risks (PPRL) } \text { if } \\
\text { so, what is the extent of these consultations, } \\
\text { what are their nature? what is the content of } \\
\text { the exchanges? what are the impacts of } \\
\text { these events on the documents and their } \\
\text { order? }\end{array}$ & $\begin{array}{l}\text { - Test of the hypothesis of an } \\
\text { expectation of } \\
\text { democratization/integration } \\
\text { of risk through the exchange } \\
\text { (possibly renewed) with the } \\
\text { populations }\end{array}$ \\
& $\begin{array}{l}\text { - If "risk culture" is } \\
\text { mentioned: have a definition } \\
\text { of what is meant by risk } \\
\text { culture }\end{array}$ \\
\hline
\end{tabular}




\section{Appendix 3}

Semi-directive interview grid for the inhabitants of the territory (INEGALITTO Project)

\section{PART I. PERSONAL CHARACTERISTICS AND LIVING ARRANGEMENTS}

\section{PERSONAL CHARACTERISTICS}

Genre, Age, Family situation, number of inhabitants in the household, number of dependent children, education level of dependent children, membership of an association, socioprofessional categories, place of work, means of transport used to get to work

\section{LOCATION}

\section{Respond Respondent's sector: depending on the field}

Are you :

o Owner

o Tenant

Is it a :

o Main residence

o Secondary residence

Is your dwelling a :

o Single-storey house

o Single-family house with one floor

o Ground floor flat

o Flat with upper floor

o Private holiday bungalow

o Other:

When was your accommodation built?

Are you a native of the commune? YES NO

o If not, what was your previous commune (please fill in the department number)?.

o If no, why did you move to the region?

- Work

- Living environment

- The coastline

- Children's education

- Family reason

- Proximity to La Rochelle

- Other:.

How long have you lived in the commune?

o 0-5 years 
o 5-10 years

o 10-15 years

o 15-20 years

o More than 20 years

o Don't know

Have you ever moved within the municipality?

YES NO

o If yes, for what reasons?

- Larger house

- Smaller house

- Home ownership

- For proximity to the coast

- Because of a feeling of insecurity

(frequenting the area, burglary, dangerous traffic, risk of flooding, poor night lighting, etc.)

- Following an expropriation

(declaration of public interest, application of solidarity zone, etc.)

- Other:

o If yes, in which district of the commune did you live before moving?

\section{PART II. REPRESENTATIONS AND PERCEPTIONS OF RISKS IN THE COMMUNE}

\section{PERCEPTION OF RISKS ON THE COMMUNE}

In your opinion, what are the risks present in your commune?

According to you, what are the natural risks present in your commune? (To be ranked in order of importance)

- Earthquake

- Storm

- Marine submersion

- Heat wave

- Snowfall

- Landslide

- Coastline retreat

- Hurricane

- Other: 


\section{PERCEPTION OF FLOOD RISK}

By flood risk we mean any possibility of flooding, whether rapid or slow, of an area that is usually out of water.

To the best of your knowledge, has the commune ever experienced flooding?

YES NO DON'T KNOW

o If yes, when was the last time the municipality was flooded?

o If yes, did you experience this event?

YES NO

o If yes Among this list, what were the main difficulty(s) you encountered during and after the event?

- Obtaining supplies of food and equipment

- Ensuring daily travel

- Reaching the emergency services

- Being compensated for property and possessions

- Living through expropriation measures in solidarity zones

- To integrate a psychological support unit

- Other:.....

How many floods have you experienced since you have lived in the commune?

- None

- 1

- Between 2 and 5

- More than 5

- Don't know

To your knowledge, are there any flood markers in your commune?

YES NO DON'T KNOW

Since you have lived in the commune, would you say that the ocean has :

- Advanced on the land

- Not moved

- Receded

- Don't know

Do you think that the evolution of the coastline could represent a risk for your place of residence?

YES NO DON'T KNOW

\section{PERCEPTION OF THE TERRITORY'S VULNERABILITY}


By coastal risks we understand each of the natural phenomena that cause risks to coastal populations (maritime flooding inland, retreat of the coastline due to erosion, dune overhang, etc.).

Do you think that the commune is subject to coastal risks?

\section{YES NO DON'T KNOW}

o If yes In your opinion, which sectors of the commune are most exposed to coastal risks?

- The La Marina sector

- Les Groies and L'Abbaye sectors

- The town hall area

- The whole commune

- Other:

- Don't know

o If yes, do you feel sufficiently protected against coastal risks?

YES NO DON'T KNOW

o If yes, why?

o If not, what do you think are the actions to be carried out in priority :

- Reinforce the dykes of the commune

- More control of land use in the commune

- Ensure more public meetings on the issue of risks

- Reinforce prevention information to the population

- Innovate in construction techniques (housing on piles, etc.)

- Strengthen assistance to victims (state, municipal, insurance aid, etc.)

- Other:

- Don't know

Are you aware of the concept of territorial vulnerability?

YES NO DON'T KNOW

o If yes, how do you define it?

Do you think that your daily actions increase the vulnerability/fragility of the territory to coastal risks?

YES NO DON'T KNOW

o If yes, what kind of actions are they? . 
o If yes, what is/are the impacts of these actions?

o If no, why not?

Are you aware of the concept of resilience?

YES NO DON'T KNOW

o If yes, how do you define it?

Are you aware of a resilient/preventive planning policy for coastal risks in your municipality?

YES NO DON'T KNOW

o If yes, which one(s)?

\section{PART III. PREVENTIVE INFORMATION ON THE COMMUNE}

\section{DEFINING PREVENTION}

What is prevention in the face of coastal risks in your opinion?

How is it being implemented in the municipality territory?

Who do you think is in charge of its implementation?

- The mayor and the municipal councillors

- The fire department of the municipality

- The associative sectors of the municipality

- The police powers of the Region

- There is no implementation, it is up to each inhabitant to be informed and prepared 
- Other:

- Don't know

\section{PREVENTION AND HOUSING}

Is your home in a flood zone?

\section{YES NO DON'T KNOW}

o If yes, did you know this before purchasing/renting this property?

YES NO DON'T KNOW

o If yes, how did you know?

- When you bought your property (buyer/landlord information document)

- Following a public meeting at the town hall

- Following personal research

- Following a flood that affected your property

- Following a neighbourhood discussion

- Other

.

- Don't know

o If you don't know, do you know how to get the information?

Have you ever considered moving due to feeling insecure about the coastline?

YES NO DON'T KNOW

To your knowledge have there been any expropriations in the municipality due to coastal risks?

YES NO DON'T KNOW

o If yes, do you know how many and where:

o If yes, do you think that this could one day concern you?

YES NO DON'T KNOW

Why? 
o If no, do you think it could be implemented in the commune?

YES NO DON'T KNOW

Why?

\section{PREVENTION AND DAILY LIFE}

If a flood were to occur today, what would be your priorities? (Please rank in order of importance)

- Protecting and securing your belongings

- Leave your home temporarily

- Pick up your children from school

- Shopping for food and necessary materials

- Wait in your home until the alert is over

- Wait for safety instructions about the event

- Other:.

- Don't know

How do you think you would be alerted to a flood in the municipality?

- By municipal sirens

- By a phone call from the municipal services

- By radio, specify which one(s):

- By the TV news

- By the press

- By your neighbours

- By yourself

- Other :

- Don't know

Have you ever participated in crisis simulation exercises?

YES NO DON'T KNOW

o If yes

- Which situation was simulated?

- Where did it take place?

- Were you aware of this exercise? YES NO

- Do you know who sponsored this exercise?

YES, specify:

NO

- Do you know who led it?

YES, please specify:

NO 
- Can you tell me who participated?

(If children are present) - Have your children ever participated in any risk simulation or training exercises in their school?

YES NO DON'T KNOW

o If yes

- What situation was simulated?

- Were they aware of this exercise? YES NO

- Can you tell me who led this exercise?

Have you ever had any information on what to do in a crisis?

YES NO DON'T KNOW

o If yes, what kind of information was it?

- Brochure

- Municipal newspapers

- Information meeting

- Simulation exercise

- Website

- Association event

- Other :

o If yes, who gave you this information?

- Municipal services

- Police or gendarmerie services

- Fire brigade

- School services

- Association(s), specify:

- A neighbour/acquaintance

- Personal research

- Other :

o If yes, do you have any questions following this information?

YES NO DON'T KNOW

Do you know where to find/complete this information? 
To your knowledge, are there any public meetings or municipal events dealing with the issue of coastal risks and their prevention in the municipality?

YES NO DON'T KNOW

o If no, would you be interested in such events?

YES NO DON'T KNOW

o If yes, what topics or actions would you like to see on the agenda?

o If yes, have you already attended one/any of these events or meetings?

YES NO

o If yes, can you specify the subject(s) of this/these event(s):

o Please specify the type(s) of event(s) or meeting(s):

o If yes, did you actively participate in these meetings (or events)?

YES NO DON'T KNOW

o If yes, can you please specify what you did at them?

o If yes, what impact do you think this participation had?

o If yes, would you be interested again in participating in this kind of event, meeting?

YES NO DON'T KNOW

o If no, why not?

\section{PART V: SPATIAL REPRESENTATION OF COASTAL RISKS}

\section{SPATIAL REPRESENTATION}

The aim of this last part is to identify the spatial representation you give to certain elements or features present in your environment, in your place of life. 
To do this, simply annotate the map in a personal and spontaneous way, in connection with the following requests:

- In blue draw the areas flooded by marine submersion,

- In black draw the areas that have been subject to expropriation procedures with regard to coastal risks,

- In red draw the coastline by 2040 ,

- In green draw the protection measures which you think are necessary to protect the area (creation of dykes, dune barriers, deconstruction zones and maintenance of undeveloped areas, creation of information areas, etc.).

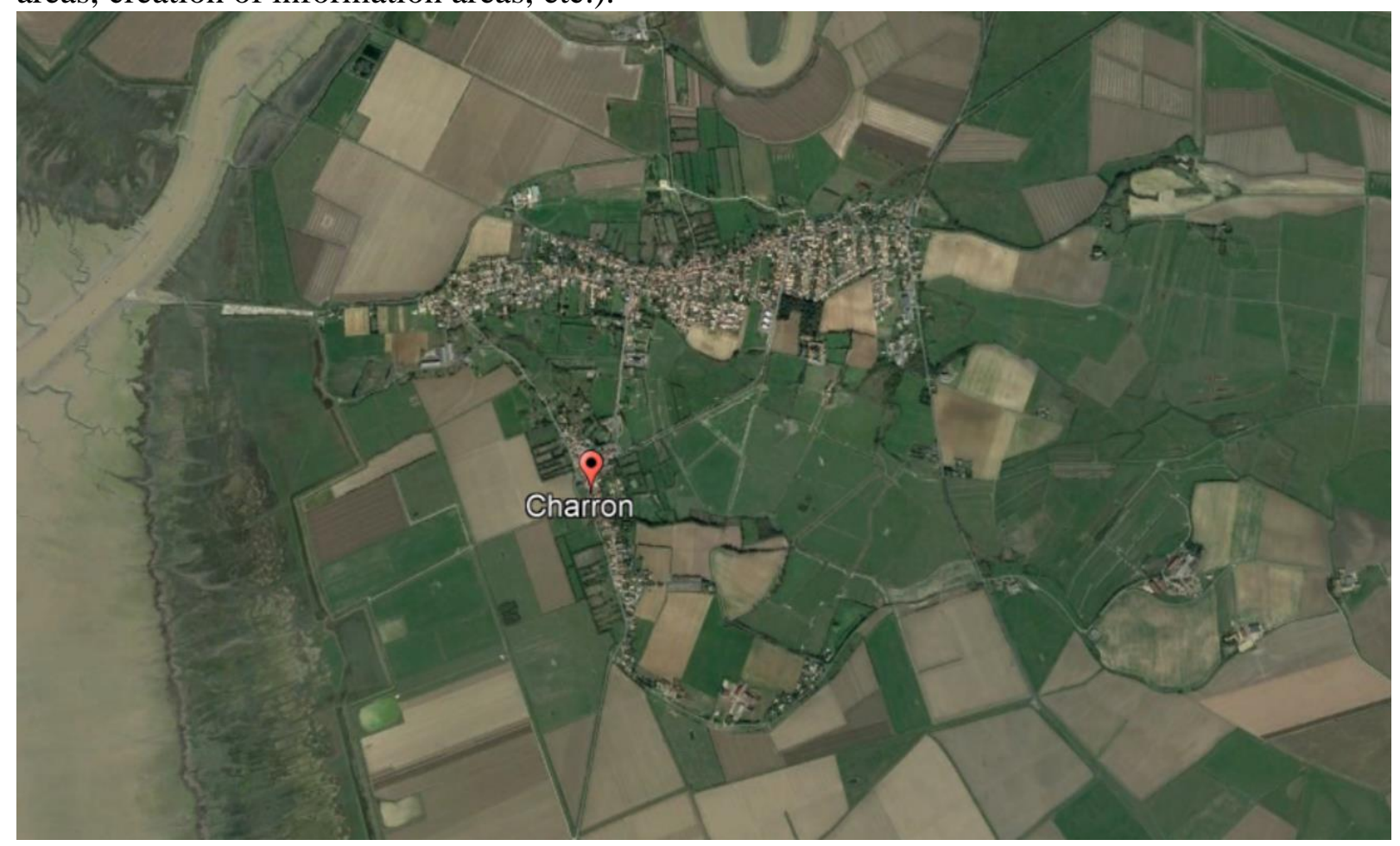

\section{Charron municipality}

